\title{
Creating a reference source of the light flux on the basis of LED lamps
}

\author{
Chaikova L.D \\ Republican Unitary Enterprise \\ "Belorussian State Institute of Metrology" - BelGIM \\ 93, Starovilensky trakt, Minsk, 220053 \\ Phone (375-017) 334-98-20, fax (375-017) 288-09-38 \\ e-mail: optic@,belgim.by
}

The results of the work to create the layout of standard lamps of luminous flux on the basis of serial production of LED lamps. Substantiates their physical circuit. We describe the principle of selection, testing and basic metrological characteristics.

Introduction. Intensive development of lighting technology, the complexity and improving the ergonomic requirements for the coverage of industrial and residential buildings, the use of optical radiation in medicine, the development of new types of lighting in household appliances, in the television makes it necessary to solve more complex metrological tasks in the field of photometry. All the more widespread sources of illumination based on no thermal effect: LED and compact fluorescent lamps. The progress made over the past 10 years, in the field of energysaving light sources, comparable, and in some ways superior to the revolution of the late 19th century, when there was a shift from the lights on the basis of fuel combustion to electric light bulbs. However, to ensure uniformity of measurements of the photometric parameters of such sources is necessary to use methods and means that differ from those used in classical photometry. Choosing the incandescent bulb, the consumer is primarily focused on its power consumption. This characteristic is usually enough to assess that all the properties of light bulbs of any manufacturer. However, this strategy does not work when it comes to sources with a spectrum very different from that of incandescent lamps. And this is all kinds of energy saving lamps. In this regard, national, interstate and international standards, recommendations of the International Commission on Illumination (CIE) include a list of the main characteristics of the subject to mandatory registration, the luminous flux, color temperature, luminous intensity, color coordinates and brightness of continuous and pulsed radiation sources.

The strength of the light part of the international system of units (SI) as a basic unit, and thus, there is a specific precedent in the system when secondary to their field physical quantity is fundamental to the relationship of physical quantities. In 2003, it has been redesigned state verification schedule for means of measuring light values of continuous and pulsed radiation, which is entered in the standard unit of luminous flux - lumen. Currently, the majority of metrologists, working in the field of optical radiometry, are inclined to believe that the main or base value in optical radiometry must be considered flux (power) and the unit of watts (W), and, accordingly, in photometry - the luminous flux and the unit lumen . In 2015 BelGIM were completed to create continuous luminous flux of the radiation source of national standard unit of NE 28-16. The benchmark of the two main methods implemented luminous flux measurement: using the integrating sphere and goniospektroradiometra.[1] For more than three decades, a reference optical radiation source for calibration of photometric balls were incandescent lamp type IIB and their foreign counterparts, imitating illyuminant A CIE (illyuminant A - black body 
with the thermodynamic temperature of $2856 \mathrm{~K}$ and the chromaticity coordinates of $\mathrm{x}=0.4476$ and $y=0.4074)$. They also acted as transfer standard when making international comparisons.

However, the situation with the metrological support of the luminous flux measurement is significantly deteriorated in recent years. Firstly according to the requirements of international standards for calibration of photometric balls you must use a source with the spectral distribution of the radiation power (MDS) as close as possible to the MDS test radiation source. As seen from the Figure 1 MDS spectrum CFLs, white LEDs and incandescent lamps vary considerably.[2]
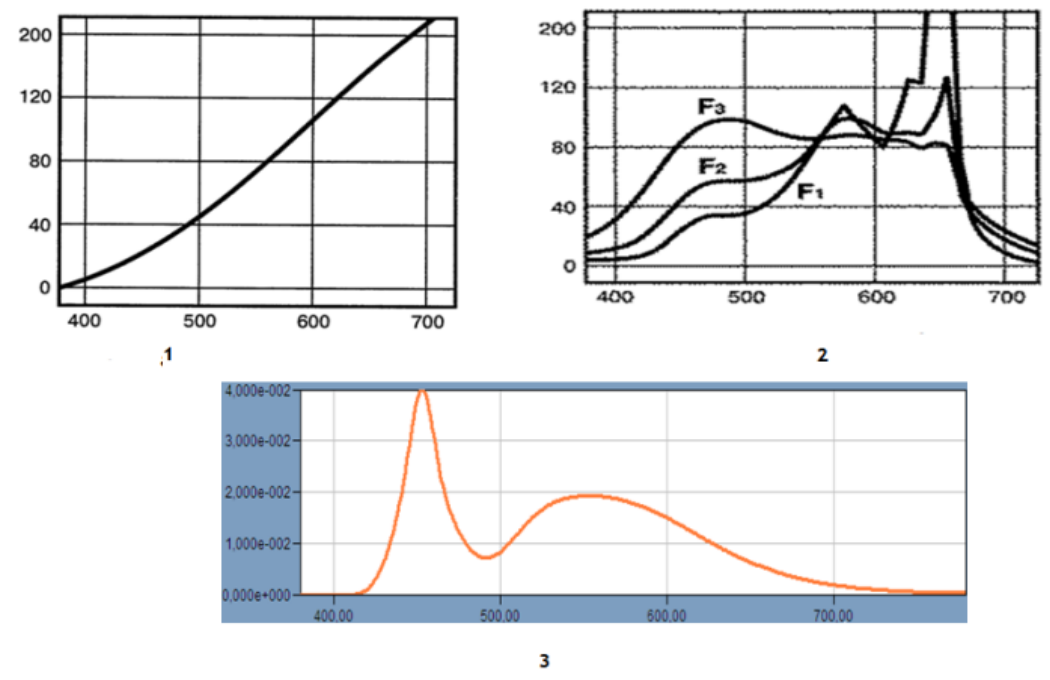

1 - Illuminati CIE A; 2 - compact fluorescent lamps; 3 - LED white light.

\section{Drawing 1. View of the spectral distribution of the radiation power of different light sources.}

Secondly, after the entry into force of the Directive EC 2005/32 / EG the world's major producers ceased the production of incandescent light bulbs. At the same time it was closed and the production of standard photometric lights. Similar production in the countries of the former USSR were closed in the 90's. Thus, the relevance of this issue is not in doubt.

Analysis of publications in the scientific literature and reviews of LED products market has revealed three main types of LED lamps:

Headlamp based on color mixing. They are based on multi-chip LEDs, most - three-component (RGB-LED), having in its composition three semiconductor emitters of red, green and blue glow, united in one body. Currently, virtually disappeared from the market, since they have very low color quality performance and energy efficiency. Lamps on the basis of phosphor LEDs. The phosphor LEDs, created on the basis of ultraviolet or blue LEDs, have in their composition a layer of a special phosphor, which converts the result of the LED light emission of photoluminescence in a relatively wide spectral band with a maximum in the yellow part of the spectrum. Lamps made by LED-filament technology. LED-filament is a metal wire which has consistently placed a large number of small ultraviolet or blue LEDs coated with phosphor layer common. Thus, simulated filament incandescent lamp.[3]

The same analysis revealed that one of the main sources of instability in the luminous flux of LED lamps is the so-called built-in power supply driver, as well as the power mode from the AC 
source. With this in mind, we decided to upgrade the lamps, to withdraw from their drivers and provide power using an external precision DC. Since, according to the international standard CIE S 025 lamp used to calibrate photometric sphere, must have not only the spectral distribution of the emission power, but also the radiation pattern as close as possible to that of the test light source, we have carried out the study charts the direction of the main types of LED bulbs direct replacement and lamp type CIP. [4,5] The results are shown in drawing 2.

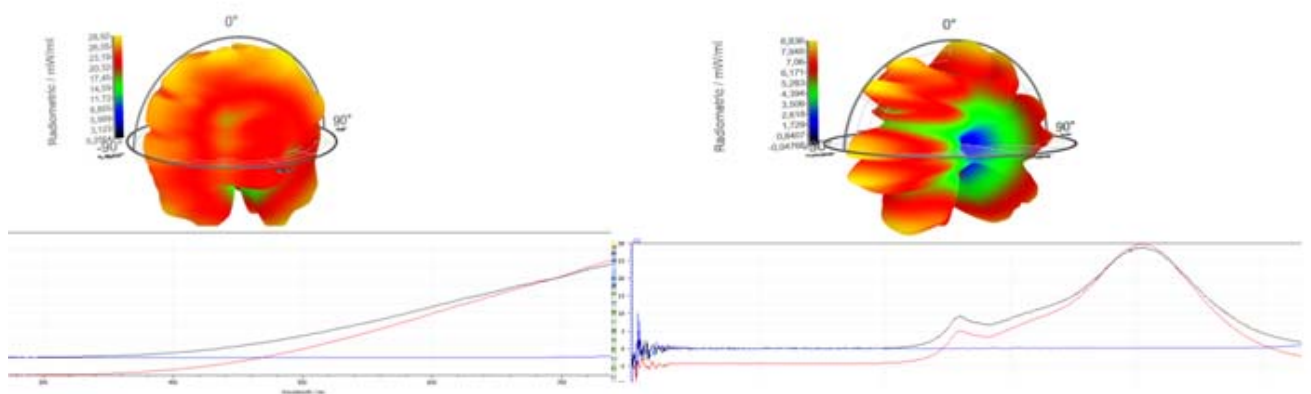

1

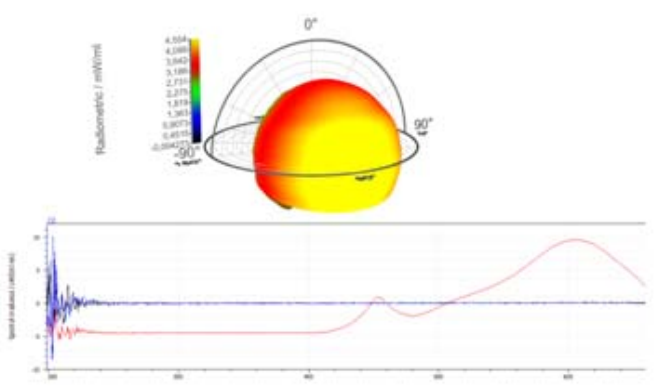

3

1 - lamp CIP; 2 - lamp type LED-filament; 3 - a lamp phosphor based LEDs.

Drawing 2. View of the spectral distribution of the radiation power and directivity pattern of different types of light sources

On the basis of the research as a basis for making the layout of the reference luminous flux lamps we have selected 2 lamps made on the basis of technology LED-filament and phosphor LEDs. Exterior lamps is shown in drawing 3

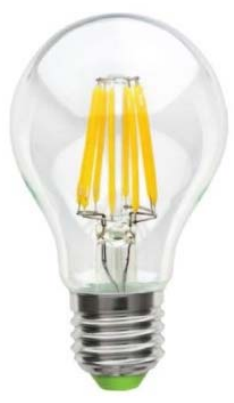

1

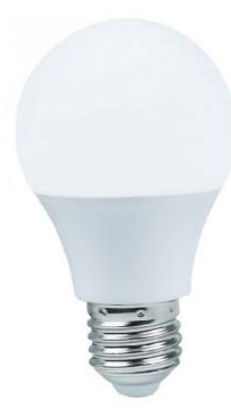

2

1- Lamp type LED-filament; 2 - a lamp phosphor based LEDs.

\section{Drawing 3. Appearance lamps}

Each lamp is annealed in an operating mode with an external power supply within 80 hours to control the photometric parameters of every 10 hours. The measurement results are shown in Table 1 
Table 1. Results of stability studies luminous flux standard lamps layouts

\begin{tabular}{|l|c|c|c|c|c|c|c|c|}
\hline \multirow{2}{*}{ lamp type } & \multicolumn{6}{|l}{ Luminous flux after $\mathbf{~ h o u r s ~ a n n e a l i n g ~} \mathbf{~ m}$} \\
\cline { 2 - 9 } & $\mathbf{1 0 ~ h}$ & $\mathbf{2 0 ~ h}$ & $\mathbf{3 0 ~ h}$ & $\mathbf{4 0 ~ h}$ & $\mathbf{5 0 ~ h}$ & $\mathbf{6 0 ~ h}$ & $\mathbf{7 0 ~ h}$ & $\mathbf{8 0 ~ h}$ \\
\hline $\begin{array}{l}\text { LED- } \\
\text { filament 1 }\end{array}$ & 830 & 846 & 837 & 820 & 810 & 815 & 820 & 827 \\
\hline $\begin{array}{l}\text { LED- } \\
\text { filament 2 }\end{array}$ & 850 & 820 & 840 & 820 & 833 & 830 & 820 & 830 \\
\hline $\begin{array}{l}\text { LED- } \\
\text { luminophore } \\
1\end{array}$ & 1500 & 1520 & 1520 & 1550 & 1510 & 1520 & 1525 & 1530 \\
\hline $\begin{array}{l}\text { LED- } \\
\text { luminophore } \\
1\end{array}$ & 1510 & 1550 & 1550 & 1530 & 1540 & 1525 & 1535 & 1520 \\
\hline
\end{tabular}

References:

As can be seen from the above data that the generated layout luminous flux standard lamps based on LED showed good stability $( \pm 4 \%)$. Thus, it demonstrated the correctness of the approach underlying the layout. However, before the validation of lamps as the working standard unit of luminous flux achieved metrological characteristics they can and should be improved. To this end at the next stage of the study, scheduled for the second half of 2017, we will retrofit lamps produced active cooling system based on Peltier elements. Also it planned to create a set of not less than 4 lamps, covering a range of CCT from 2700 to $6500 \mathrm{~K}$

Bibliography

1) Н.В.Баковец, С.В.Никоненко, Д.В.Скумс, О.Б.Тарасова Национальный эталон единицы светового потока. Фотометрический и светодиодный блоки. «Метрология и приборостроение» № 2-2016

2) Скумс Д.В., Тарасова О.Б., Липлянин А.А., Никоненко С.В., Погрешности измерения освещенности создаваемой светодиодами.Сборник трудов XIX научно-технической конференции “Фотометрия и ее метрологическое обеспечение” 16 19 апреля 2013 г.Москва.

3) Н. В. Баковец, В. А. Длугунович, А. В. Галыго, А. В. Исаевич, Е. В. Луценко, С. В. Никоненко, О. Б. Тарасова, Д. В. Скумс .Метрологическое обеспечение исследований оптических характеристик твердотельных источников излучения / Metrological support of measurements of the optical characteristics of solid-state light source. Сборник статей 10-го Белорусско-Российского семинара "ПОЛУПРОВОДНИКОВЫЕ ЛАЗЕРЫ И СИСТЕМЫ НА ИХ ОСНОВЕ”. 26-29 мая 2015 г. Минск, Ковчег, 2015Стандарт CIE S 025 Test Method for LED Lamps, LED Luminaires and LED Modules

4) Гост Р 8.888 -2015 Государственная система обеспечения единства измерений. Светодиоды эталонные некогерентного излучения. Технические требования

5) Стандарт CIE S 025 Test Method for LED Lamps, LED Luminaires and LED Modules 